\title{
Effect of Tourism Awareness Work Culture on Visiting People Satisfaction at Muaro Lasak Beach
}

\author{
Aldri Frinaldi ${ }^{1}$, Afriva Khaidir ${ }^{2}$, Yulvia Chrisdiana ${ }^{3}$, Muhammad Nazhif Asy’ari ${ }^{4}$, and Anton \\ Sugiono $^{5}$ \\ \{ aldri@fis.unp.ac.id ${ }^{1}$, af.khaidir@gmail.com², chrisdiana2009@gmail.com ${ }^{3}$, \\ mhd_nazhif@yahoo.co.id ${ }^{4}$, antonsugiono38@gmail.com ${ }^{5}$ \} \\ Magister Program of Public Administration, Universitas Negeri Padang, Indonesia ${ }^{1,2,4,5}$ \\ Sekolah Tinggi Ilmu Administrasi Sandikta, Bekasi, Jawa Barat, Indonesia ${ }^{3}$
}

\begin{abstract}
The presence of tourism awareness work culture determined the number of visiting people to West Sumatera. One of the most visited attraction was Muaro Lasak Beach which is not only sought by domestic but also overseas people. The aim of this research was to see the effect of tourism awareness work culture among tourism community in increasing the visiting people satisfaction in Muaro Lasak Beach. This aim was approached by using phenomenologyqualitative method that used observation, interview, and documentation study as the data collecting technique. The result showed that the satisfaction of visiting people was still low because there was a gap between their expectation and the service ther received. It concluded that visiting people satisfaction was influenced by the implementation of tourism awareness work culture among tourism community.
\end{abstract}

Keywords: Tourism, Apparatus Work Culture, Tourism Conscious Work Culture, Visitor Satisfaction.

\section{Introduction}

Tourism sector is an important asset in improving a nation's development [1][2].Four important elements that must be integrated with tourism policy are attraction; accessibility, facilities, and infrastructure; accommodation (hotel and restaurant); and tourism organization which actively supports tourism management activities [3].

Tourism management system is a two-way system which cannot be separated with the actors who run the system and build an interdependence relationship. They are government, private (tourism community), and surrounding community [4]. The improvement of visiting people satisfaction is determined by tourism service quality, the facilities, and other factors that cause tourist convenience [4].This research assumed "other factors" to be tourism awareness work culture oftourism communitythat significantly influences numbers of visitors. 
Indonesia Government through Strategies Plan of Tourism Ministry 2015-2019 that also conducted by local government targets the increasing of visitor and push the state revenue from tourism sector because it contributes to the increasing of internally generated revenue that can trigger development program and the improvement of sovereign economy sustainably[5][6]. So, in order to increase the economic and social impacts of the tourism sector, efforts are needed to build a tourism consciousness work culture among related officials. These efforts are important to bring satisfaction to people who visit a tourust site.

Padang City is the capital of Sumatera Barat Province that has numerous tourist attraction such as culture, old building, food, and, nautical beauty. But the absorption of internally generated revenue from it is still not maximum that caused by the lack of coordination between government and tourism community. Based on BPS data from 2016, the number of tourists that visited Padang City from 2014 to 2016 is increasing, that is as much 3.254.359, 3.355.722, 3.673.493 people respectively. One of the most visited attractions is MuaroLasak Beach especially in weekend, national holiday, and religious holiday which cause congestion near the attraction. There was an assumption that it indicates visiting people satisfaction. But it must be elaborated again, is it true because the presence of tourism awareness work culture from tourism community? Thus, we proposed this problem; How is the effect of tourism awareness work culture among tourism community on the improvement of visiting people satisfaction in Muaro Lasak Beach of Padang City?

The Act Number 10/2009 about Tourism defined tourism as kinds of tourism activities that are supported by the service and facilities provided by the surrounding community, entrepreneurs, central and local government. The complete facilities can attract tourist, become income source, and contribute to regional development such as addition of foreign exchange, job opportunities, cultural unification, and environmental conservation.

Tourism is a mega business that has three pillars; citizen, government, and stakeholder[7]. It also needs the involvement of mass media [8] that functions as media socialization media and aims information dissemination about tourism to all society. Tourism activities aim to increase the economic development and social welfare, toeliminate poverty and unemployment, preserve culture and nature, advance the culture, lift the nation's image and nationalism [9]. To achieve this aims, Community Based Tourism (CBT) concept is developed as the tourism development strategy [10]. CBTaims the improvement of public participation economically, to give public a power to manage the tourist attractionbecause public participation is the basic requirement of sustainable tourism development [11].

While, work culture is a visible and invisible basis of an individual, viewed from value and belief perspective, understanding of work, norm, mindset, and attitude of a person or group of people that can help to achieve organizational goal it accompanied by good leadership, healthy communication, time management, and a fair reward and punishment system [12][13].From that definition, we derived tourism awareness work culture as a work culture that owned by tourism actors (government, tourism community, and visiting people) that can assist the achievement of tourism objective if it also accompanied by those things and a good coordination among the actors.

Understanding work culture can be cultural and social interactions that can be built with linguistic elaboration both in structuralist or post-structualist procedures-representation and material social-relations. Culture can be see as the practice of making meaning, consequently, organizing meta-semiotic traits, so it can be witnesses a process that has connection to express culture that is understood as a "way of life". Understanding this "way of life" is also based on social environtment theory where people interact with each other and do things together and with their environtment. Communities around the tourist sites cooperate with other communities and also the government in creating satisfaction for tourist who come to travel. And also this "way of life" will become a habit and will directly or indirectly have an impact on the quality and satisfaction of visitors. This will be correlated with an increasing in visitors for the future [14] [15] [16]. 
The Act Number 10/2010 about Tourism stated two interrelated terms, tourism entrepreneur and tourism business. Tourism entrepreneur is a person of a group of person that do a tourism business, meanwhile tourism business is a business that provide goods/services to fulfill the needs of visiting people and tourism entrepreneur. The term 'tourism' is defines as all the multidimensional activities that are everybody's need where the interaction between the tourist, surrounding citizen, government, and tourism entrepreneur happened. Based on three terms above, we proposed "tourism community" term that means "all people who involve in tourism activities and work to fulfill the visiting people' need in order to establish a healthy interaction between the visiting people and the tourism community such as lodging provider, restaurant/café, travel agent, souvenir seller, and the traders around the attraction".

Previous studies proved the influence of each tourist entrepreneur on tourist satisfaction such as; (1) availability of hotels, restaurants, souvenir shops, and transportations around the tourist attraction[17]; (2) The taxi service and entertainment during the trip provided by travel agents [18]; (3) The performance of tourist guide during being in the attraction [19][20]. In this research will be conducted a study on the effect of all part of tourism entrepreneur named 'visiting people' on visiting people satisfaction.

Satisfaction is defines as "the consumer's fulfillment response" where customers compare the perceived product and their initial expectation. The comparison result then determines whether they are satisfied or not[121][22][23]. Unlike other studies, it uses 'visiting people' term that means 'masyarakat berkunjung' in Bahasa and not 'tourist'. The prefix ber- in Bahasa means 'do something'[24]which is part of desire.This concept matche swith satisfaction concept that emphasizes one's expectation.Previous research showed that work culture positively influenced service quality and customer satisfaction for $77.6 \%$ and $6.8 \%$ respectively[25].

\section{Methodology}

This is a phenomenology-qualitative research that observes phenomenon happened naturally to collect the data of tourism awareness work culture and visiting people satisfaction[26]. The observation of work culture phenomenon is based on ten elements of tourism awareness work culture, named safety, orderly, cleanness, cool, beautiful, friendly, memorable, polite, well mannered, and responsive, meanwhile the observation of visiting people satisfaction is based on five indicators named enjoy, happy, complete facilities as expected, information availability through advanced equipment, performance of tourism service, and visiting people's expectation [27][28]. The sample was taken by using purposive sampling. The data were collected by doing observation and interview with 50 tourism community and 300 visiting people in Muaro Lasak Beach from June to August 2017. The data were analyzed by using Miles and Huberman model which covers data reduction, presentation, verification, and conclusion which is then triangulated by data re-check from various sources, methods, times, and membercheck.

\section{Finding and Discussion}

The observation and interview result about tourism awareness work culture showed that; (1) The visiting people feel unsafe because of thuggeryaround the attraction who asks for money forcefully; (2) The parking attendant are not orderly in setting the parking fare and the arrangement. The chaotic also caused by the traders who do not comply the open hour regulation; (3) The low public awareness to throw the rubbish in the garbage bin even though the officer has provided the bin, banner, and written announcement; (4) Only few spots in the attraction is overgrown with ornamental plants and shady trees eventhough there were already chairs and tables for rent; (5)The beauty of this attraction depends on the arrangement of supporting facilities such as trading area, parking lot, and selfie area; (6) The tourism community has responded the question form visiting people friendly and gently; (7) There were no souvenir store provided near this attraction; (8) Polite and (9) Well mannered. Tourism community has showed politeness in the interaction with the visiting people; (10) Tourism communities were not responsive in providing cultural information center, customs, and event 
that will be held. From all ten tourism awareness work culture concept in tourism community, four items were not implemented optimally, named safety, orderly, cleanliness, and souvenir sales.

Furthermore, The observation and interview result about visiting people satisfaction showed that; (1) Visiting people stated that they enjoyed after visiting the attraction even they wanted to come again;(2) Visiting people felt happy after coming back from there because there were many things have changed from previous years; (3) They wanted more improved facilities such as souvenir store, health and safety centre, and information accessibility from advanced media; (4) They assessed that the performance of tourism service provided were quite good because the tourism community treated them politely and gently except the parking officer; and(5) The expectation of visiting people are high. They expect clarity of parking rate, eradication of thuggery, procurement of parking lots which does not disturb the pedestrian path, the improvement of facilities and infrastructure, development of information, health, and first aid center, and the presence of officer around the attraction. Description above suggested that there are still discrepancy between the visiting people's expectation and the tourism service they received. The wide gap was caused by the poor practice of tourism awareness work culture values among the tourism community in Muaro Lasak Beach.

\section{Conclusion}

Tourism is one of the important sectors that need to be develop innovatively because it has a large influence on improving the living standards of the surrounding communities. Revenue and employment can grow if there is a continuous growth and increasing community visits to tourist sites. In other hand, based on findings and discussion above, we concluded that the practice of tourism awareness work culture among the visiting community was still lacking in many aspects. There was the discrepancy between the visiting people's expectation and the tourism service they received caused by the poor practice of tourism awareness work culture values. The managerial implication of this research is to guide the optimization of tourism awareness work culture practicein order to improve the visiting people satisfaction. Theoretically, the introduction of "visiting people satisfaction" and "visiting community" as new terms is a novelty of this research because someone who visits an attraction has a desire, urge, and wish that push them to visit it.Thus, this term is relevant with satisfaction concept which essentially compares expectation and performance

Acknowledgments. The author would like to express his gratitude and appreciation to the Universitas Negeri Padang through the Institute of Research and Community Service (LP2M) for funding the research under A Scheme of Postgraduate Study with UNP DIPA 2017 Budget Year. With the title "Building Model Tourism Awareness Work Culture Policy among Apparatus and Society of Tourism in an effort to increase Community Satisfaction Visiting Tourism Sites in West Sumatra”. 


\section{References}

[1] Soebagyo 2012 Strategi Pengembangan Pariwisata Di Indonesia Jurnal Liquidity, 1 (1).

[2] Maulana A 2016 Pengaruh Kunjungan Wisatawan Mancanegara Dan Perjalanan Wisatawan Nusantara Terhadap Penyerapan Tenaga Kerja Sektor Pariwisata Di Indonesia. Jurnal Kepariwisataan Indonesia11 (1).

[3] Sugiama A 2011 Ecotourism: Pengembangan Pariwisata Berbasis Konservasi Alam. Bandung: Guadarya Intimarta.

[4] Zaei M Eand Zaei M E2013 The impacts of tourism industry on host community. European journal of tourism hospitality and research 1(2), 12-21.

[5] Rosita R., Marhanah Sand Wahadi W H 2016 Pengaruh Fasilitas Wisata Dan Kualitas Pelayanan Terhadap Kepuasan Pengunjung Di Taman Margasatwa Ragunan Jakarta Jurnal Manajemen Resort Dan Leisure 13(1).

[6] Ahmar A, Nurlinda Nand Muhani M 2016 Peranan Sektor Pariwisata Dalam Meningkatkan Pendapatan Asli Daerah Kota Palopo Jurnal Equilibrium.

[7] Suartini N N and Utama M S 2013 Pengaruh Jumlah Kunjungan Wisatawan, Pajak Hiburan, Pajak Hotel Dan Restoran Terhadap Pendapatan Asli Daerah Di Kabupaten Gianyar. E-Jurnal Ekonomi Dan Bisnis Universitas Udayana 2 (3).

[8] Hamzahn A 2015 Peran Masyarakat Dalam Mewujudkan Pariwisata Berkelanjutan Melalui Pengembangan Daya Tarik Wisata Kabupaten Bulukumba di Sulawesi Selatan. Jurnal Kepariwisataan 9(2).

[9] Chamdani U 2016 Pengaruh Publikasi Sadar Wisata di Media Rado Terhadap Kalangan Pelajar. Jurnal Kepariwisataan Indonesia 1 (1).

[10] Restyanto A R 2016 Pendidikan Sadar Wisata Untuk Masyarakat Di Sekitar Obyek Wisata Air Terjun Sri Getuk Desa Bleberan Playen Kabupaten Gunungkidul. Spektrum Analisis Kebijakan Pendidikan 5 (3), 266-278.

[11] Tolkach D and King B 2015 Strengthening Community-Based Tourism in a new resource-based island nation: Why and how?. Tourism Management 48, 386-398.

[12] Frinaldi A 2011 Analisis Budaya Kerja Disiplin dan Kesadaran Waktu Pegawai Negeri Sipil (Studi pada beberapa Pemerintah Daerah di Sumatera Barat). Jurnal Demokrasi, 10 (2).

[13] Frinaldi A 2014 Pengaruh Budaya Kerja Pegawai Negeri Sipil Terhadap Pelayanan Publik di Dinas Catatan Sipil dan Kependudukan Kota Payakumbuh. Humanus, 13 (2), 180-192.

[14] Frinaldi A, dkk. 2019. Policy Management To Develop Tourism Work Culture Consciousness And Increasing Visitng People's Satisfaction. Jurnal Studi Pemerintahan. Vol.10 No.1

[15] Frinaldi A, dkk. 2019. The Effect of Driver Service Quality on Passenger Satisfaction in Public Transportation. International Conference on Pubic Administration, Policy and Gove rnance (ICPAPG 2019). Advances in Economics, Business and Management Research. Vol.125

[16] Frinaldi, dkk. 2019. CHAMPSCulture to Increase Employee Performance. Humanus. Vol.18 No.1 Page: 114-127

[17] Frinaldi A 2017 The Influence of Driver Work Culture and Service Quality on Citizen Satisfaction with Mass Transportation. Proceedings Of The International Conference On Ethics In Governance (ICONEG 2016). Makassar

[18] Frinaldi A and Embi M A2011Pengaruh Budaya Kerja Etnik Terhadap Budaya Kerja Keadilan Dan Keterbukaan Pns Dalam Membangun Masyarakat Madani Dan Demokrasi (Studi Pada Pemerintah Kabupaten Pasaman Barat). Humanus 10 (1), 52-61.

[19] Frinaldi A and EmbiMA2012The Impact Of Ethnic Work Culture On Civil Servant Work Culture (A Case Study Of Work Culture Punctuality And Transparency Of Public Service In Pasaman Barat). Proceeding Public Services And Utilities (pp. 22-39). Malang: UB Press and Faculty Of Administrative Science.

[20] Frinaldi A and Embi M A 2015 Influence Of Public Service Quality In Citizen Satisfaction (Study In Private Hospital Y In Padang, West Sumatra Province). Jurnal Studi Pemerintahan: Journal of Government and Politic6 (1).

[21] Song H, Van Der Veen R, Li G and Chen J L 2012 The Hong Kong Tourist Satisfaction Index. Annals of Tourism Research 39 (1). 459-479.

[22] Latiff K and Imm N S 2015 The Impact Of Tourism Service Quality On Satisfaction. International Journal Of Economics \& Management, 9. 
[23] Chang K C 2014 Examining The Effect f Tour Guided Performance, Tourist Trust, Tourist Satisfaction, and Flow Experience on Tourists' Shopping Behaviour. Asia Pacific Jurnal of Tourism Research, 19 (2), 219-247.

[24] Cetinkaya MY and Oter Z 2016Role of Tour Guides on Tourist Satisfaction Level in Guided Tours and Impact on Re-visiting Intention: A Research in Istanbul. European Journal of Tourism, Hospitality, and Recreation7 (1), 40-54.

[25] Olliver R 2014 Satisfaction: A behavioral perspective on the consumer. Boston: McGraw Hill Education.

[26] Kotler P and KellerK2016A framework for marketing management. Boston : Pearson Education Inc.

[27] Nurhidayah and Musadad 2017 Karakteristik Pengunjung Pada Objek Wisata Danau Cipogas Kabupaten Rokan Hulu. Jurnal Online Mahasiswa FISIP UNRI 4 (2).

[28] Nurjam'an MI, MahajaniT and BudianaS2015Analisis Proses Morfologis Afikasi pada Teks Deskriptif Peserta Didik Kelas VII. Pedagogia: Jurnal ilmiah Pendidikan 7 (2), 274-283. 